Ecclesia. Studia z Dziejów Wielkopolski t. 12 (2017)

doi: $10.14746 /$ e.2017.12.4

MACIEJ SZCZEPANIAK

Uniwersytet im. Adama Mickiewicza w Poznaniu

Wydział Teologiczny

\title{
Zgubna propaganda. Reakcja nuncjusza w Warszawie na zabójstwo ks. Stanisława Streicha
}

W niedzielę 27 lutego 1938 roku w podpoznańskim Luboniu zastrzelono proboszcza parafii pw. św. Jana Bosko, ks. Stanisława Streicha. Dramat rozegrał się w czasie nabożeństwa, kiedy to kapłan po odprawionej mszy św. skierował się ku ambonie, by wygłosić kazanie. Wawrzyniec Nowak, bezrobotny radykał komunista, w obecności kilkuset dzieci oraz ich rodziców oddał do księdza kilka strzałów - najpierw w twarz, potem w plecy. Ksiądz natychmiast padł na posadzkę i już się nie poruszył. Przeprowadzona sekcja zwłok wykazała, że śmierć spowodowały strzały w głowę i w płuco ${ }^{1}$.

Wydarzenia $\mathrm{w}$ Luboniu postrzegano $\mathrm{w}$ kategorii męczeństwa $\mathrm{z}$ uwagi na fakt, że zbrodni dokonano z nienawiści do Kościoła i z pobudek ideologicznych. Mimo wybuchu II wojny światowej i doświadczeń czasów komunistycznych kult kapłana nie osłabł, a w archidiecezji poznańskiej trwa jego proces beatyfikacyjny.

Zbrodnia poruszyła ówczesnego nuncjusza apostolskiego w Polsce abp. Filippa Cortesiego. Swoje ubolewanie wyraził on w piśmie do kard. Augusta Hlonda, metropolity gnieźnieńskiego i poznańskiego, ordynariusza kapłana, o zabójstwie poinformował też Sekretariat Stanu Stolicy Apostolskiej. Wydaje się, że listy nuncjusza Cortesiego stanowią ciekawy przyczynek do badań źródłowych dotyczących lubońskiej zbrodni i ks. Streicha. Celem niniejszego

${ }^{1}$ Por. Śp. Ks. Stanisław Streich, „Miesięcznik Kościelny. Organ Archidiecezyj Gnieźnieńskiej i Poznańskiej" 53 (1938) 5, s. 218-220; W. Mueller, Błogosławiona krew-męczeństwo Stugi Bożego ks. Stanisława Streicha, Poznań 2017, s. 47; W. Mueller, Ksiadz Stanisław Streich, kandydat na oltarze, „Miesięcznik Kościelny Archidiecezji Poznańskiej” 67 (2016) 7, s. 443-447. 
artykułu jest ich analiza w świetle materiałów archiwalnych nuncjatury apostolskiej w Warszawie ${ }^{2}$.

\section{Wiadomość wzięta z prasy}

Nuncjusz Cortesi dowiedział się o zbrodni w Luboniu z prasy. „Z głębokim smutkiem dowiaduję się z gazet o niesprawiedliwym i świętokradczym zamachu dokonanym w świętym miejscu na osobie ks. Streicha, proboszcza w Luboniu"3 - rozpoczynał swój list adresowany do prymasa Polski nuncjusz w Warszawie. List pisany był we wtorek 1 marca, dwa dni po zamachu.

Ukazujący się w stolicy „Kurier Warszawski” już w poniedziałkowym wydaniu porannym zamieścił informację telefoniczną od korespondenta w Poznaniu pt. Zamordowanie proboszcza, powołując się również na depeszę Polskiej Agencji Telegraficznej: „Przebieg morderstwa był następujący: W chwili, gdy ks. Streich po mszy św., odprawionej dla dzieci, wstępował na ambonę, padł nagle strzał, który ugodził księdza w prawą skroń, kładąc go trupem na miejscu. Sprawcę zbrodni ujęto. Jest nim 47-letni Wawrzyn Nowak. Władze prowadzą dochodzenie, którego szczegóły nie mogą być tymczasem ujawnione"4.

Dzień później warszawski dziennik w wydaniu porannym podawał dalsze informacje o zamordowaniu księdza w kościele ${ }^{5}$, a w wydaniu wieczornym opisywano „szczegóły potwornej zbrodni w Luboniu” oraz informowano o potrzebie zamknięcia kościoła i jego powtórnym poświęceniu ${ }^{7}$. Specjalny korespondent z Poznania donosił, że „,wieść o zamordowaniu w kościele lubońskim [...] wywołała w całym społeczeństwie poznańskim wstrząsające wrażenie" ". Jednoznacznie stwierdzano, że ,jest to morderstwo na tle politycznym”, ponieważ „Nowak był znanym agitatorem komunistycznym na terenie Lubonia” - „morderca zeznał, że planowano jednocześnie zamordowanie drugiego kapłana miejscowego, ks. wikarego dr. Koperskiego"9. Varsavia.

${ }^{2}$ Chodzi o archiwalia zgromadzone w Archivio Segreto Vaticano (dalej: ASV), Arch. Nunz.

${ }^{3}$ ASV, Arch. Nunz. Varsavia, b. 292, fasc. 1283, 1.3.1938, k. 41: abp Filippo Cortesi do kard. Augusta Hlonda.

${ }^{4}$ Zamordowanie proboszcza, „Kurier Warszawski” nr 58 (28.2.1938), s. 5 [wyd. poranne].

5 Zamordowanie ks. St. Streicha $w$ kościele, „Kurier Warszawski” nr 59 (1.3.1938), s. 6 [wyd. poranne].

${ }^{6}$ Szczegóty potwornej zbrodni w Luboniu, „Kurier Warszawski” nr 59 (1.3.1938), s. 14 [wyd. wieczorne].

${ }^{7}$ Rekoncyliacja, „Kurier Warszawski” nr 59 (1.3.1938), s. 14 [wyd. wieczorne].

${ }^{8}$ Zamordowanie ks. St. Streicha w kościele, „Kurier Warszawski” nr 59 (1.3.1938), s. 6 [wyd. poranne].

${ }^{9}$ Tamże. 
Autor artykułu używał określeń nacechowanych emocjonalnie, np. „zbrodnia straszna w swej potworności” o „wyraźnym charakterze komunistycznej manifestacji”, „straszny czyn Nowaka”, „ohydna zbrodnia”. Przekonywał, że „potworność” zabójstwa potęgował fakt, że „zbrodniarz dokonał swego czynu podczas nabożeństwa dla dzieci szkolnych. Zgromadzone były dzieci z całej młodej parafii" 10 . Jednocześnie ukazywano ks. Streicha jako wzór kapłana służącego wspólnocie, podkreślano jego „doniosłą” działalność: „dzięki pełnej poświęcenia pracy kapłana rozkrzewiło się w Luboniu katolickie życie organizacyjne. Powstały pod jego opieką organizacje Akcji Katolickiej, a przede wszystkim katolickie stowarzyszenia robotnicze, które wpłynęły silnie na uspokojenie nastrojów społecznych"11. Zdaniem korespondenta czyn Nowaka spotkał się ,z tak energicznym odruchem całego społeczeństwa miejscowego, że przyczyni się raczej do znienawidzenia wszelkich haseł komunistycznych, których miał być posiewem. Działalność ks. Streicha na terenie parafii przygotowała już bowiem grunt dla przemiany całego środowiska”" ${ }^{2}$ - pisano 1 marca w „Kurierze Warszawskim”. Redakcja opatrzyła korespondencję z Poznania krótkim życiorysem ks. Streicha oraz informacją agencyjną PAT, w której szczegółowo relacjonowano czynności sądowo-lekarskie. Pisano o przewiezieniu zwłok do zakładu medycyny sądowej i o przesłuchaniu zbrodniarza. „Ranni kościelny Krawczyński i uczeń Pacyński zostali przewiezieni karetką pogotowia do szpitala miejskiego w Poznaniu [...]. Rannych odwiedził nad wieczorem J. Em. ks. prymas kardynał Hlond, interesując się żywo ich stanem" "13. Tego samego dnia w wydaniu wieczornym uzupełniano opis zbrodni o zeznania świadków dotyczące napastnika: „Morderca, Wawrzyniec Nowak, siedział podczas mszy św. wśród dzieci, na stopniach prowizorycznej ambony, ustawionej w pobliżu ołtarza. Przez cały czas trzymał rękę w zanadrzu płaszcza"14. Pisano, że po dokonanej zbrodni ,zbrodniarz chciał skorzystać z powstałego w kościele popłochu i usiłował uciec przez niewykończoną jeszcze nawę główną, lecz go ujęto"15. Zauważano, że w świątyni było około 200 dzieci, które zostały poturbowane w wyniku popłochu, a „w kościele znaleziono później kilka par bucików i pantofelków, które dzieci, depcąc sobie po nogach, pozdzierały jedne drugim"16.

Nie wiemy, czy nuncjusz Cortesi czerpał wiedzę o zajściach w Luboniu właśnie z „Kuriera Warszawskiego”, ale przytoczone tu fragmenty artykułów

10 Tamże.

11 Tamże.

12 Tamże.

${ }^{13}$ Tamże.

${ }^{14}$ Szczegóty potwornej zbrodni w Luboniu, „Kurier Warszawski” nr 59 (1.3.1938), s. 14 [wyd. wieczorne].

15 Tamże.

${ }^{16}$ Tamże. 
dobrze oddają ton ówczesnych relacji prasowych. W podobny sposób informowano o zabójstwie na łamach innych dzienników ogólnopolskich ${ }^{17}$.

Doniesienia prasowe wyraźnie poruszyły nuncjusza. „Nie ma właściwego słowa na potępienie podobnej zbrodni, której ofiarą stał się ten czcigodny kapłan, winny jedynie tego, że poświęcił swe życie Bogu dla zbawienia dusz i że w szczególny sposób troszczył się o dobro klasy robotniczej. Niech Bóg to sprawi, by niewinna krew pokazała jeszcze bardziej, jak zgubna jest propaganda błędów i oszczerstw szeroko szerzona wśród ludu, przyczyniająca się do tworzenia atmosfery rewolucji społecznej, której podobne krwawe akty stają się znakami poprzedzającymi" 18 - pisał abp Cortesi. List kończyły słowa wyrażające głęboki smutek i ubolewanie oraz zapewnienie o łączności w żałobie z prymasem, duchowieństwem i ludem chrześcijańskim archidiecezji.

W czwartek po Środzie Popielcowej 3 marca odbył się pogrzeb kapłana. Kondukt żałobny prowadził bp Walenty Dymek. Proboszcza-męczennika pochowano tuż przy murze świątyni, w której został zamordowany.

\section{Troska prymasa Hlonda}

Prymas Polski z całą pewnością głęboko przeżywał zbrodnię w Luboniu. W Środę Popielcową 2 marca udał się do Domu Gminnego w Luboniu, by pomodlić się przy trumnie zabitego księdza ${ }^{19}$. Odwiedził też rannych w szpita$1 u^{20}$. W sobotę 5 marca wziął udział w pontyfikalnej mszy św. w wypełnionej po brzegi poznańskiej farze ${ }^{21}$. Prasa informowała o napływających do kard. Hlonda licznych uchwałach wyrażających oburzenie społeczne ${ }^{22}$.

${ }^{17}$ M. Pryjda cytuje m.in. następujące tytuły artykułów prasowych: Szaleństwo i nienawiść („ABC”), Komunista morderca śp. ks. proboszcza Streicha w Luboniu („Gazeta Polska”), Nienawiść rodzi zbrodnię („Nowy Kurier”), Krwawa tragedia w kościele. Ksiądz zamordowany na stopniu kazalnicy („Robotnik”), Morderstwo w kościele („Słowo”), Strzelono w Polske - strzelono w Boga (,Warszawski Dziennik Narodowy”); por. M. Pryjda, Sprawa księdza Streicha na tamach prasy, „Rocznik Historyczny Lubonia” 4 (2014), s. 71-132.

${ }^{18}$ ASV, Arch. Nunz. Varsavia, b. 292, fasc. 1283, 1.3.1938, k. 41: abp Filippo Cortesi do kard. Augusta Hlonda.

${ }^{19}$ Ks. Kard.-Prymas u trumny, „Kurier Poznański” nr 101 (4.3.1938), s. 5 [wyd. wieczorne].

${ }^{20}$ Zamordowanie ks. St. Streicha w kościele, „Kurier Warszawski” nr 59 (1.3.1938), s. 6 [wyd. poranne].

${ }^{21}$ Requiem w Poznaniu za spokój duszy śp. ks. Streicha, „Kurier Poznański” nr 105 (6.3.1938), s. 12 [wyd. wieczorne].

22 Zob. np. Dalsze uchwaty w związu ze zbrodnia lubońska, „Kurier Poznański” nr 105 (6.3.1938), s. 12 [wyd. wieczorne]; Ks. prymasowi w holdzie, „Kurier Warszawski” nr 67 (9.3.1938), s. 5 [wyd. wieczorne]. W nekrologu ks. Streicha pisano o proteście, który „objawił się setkami adresów wierności skierowanych do Najwyższego Zwierzchnika naszych archidiecezyj, tudzież bardzo licznymi wiecami i zebraniami stowarzyszeń kościelnych i świeckich, wyrażających potępienie zbrodni i gotowość do nieubłaganej walki z bezbożnictwem aż do ostatecznego 
Na pismo nuncjusza apostolskiego w Warszawie arcybiskup gnieźnieński i poznański odpowiedział w poniedziałek 7 marca. Dziękował w nim za braterskie słowa wyrażające ubolewanie. „Ten kapłan, pod każdym względem przykładny, apostolski i współcześnie aktywny, nie tylko zapoczątkował i dał życie parafii pod wezwaniem św. Jana Bosko, którą erygowałem dwa lata temu w Luboniu, ale stał się motorem licznych i szczęśliwych działań katolickich i społecznych na tym robotniczym przedmieściu Poznania"23. Prymas twierdził, że ,jego gorliwa i pełna poświęcenia działalność, wspierana przez młodziutkiego księdza Koperskiego, który dwa lata temu wrócił z Rzy$\mathrm{mu}$ z dyplomem doktora teologii, zaszachowała usiłowania nielicznego grona komunistów, którzy właśnie tam znaleźli sobie siedzibę. To był powód, dla którego dobry pasterz poniósł męczeństwo" 24 .

W dalszej części listu kard. Hlond wyjaśniał, że mordercą jest Wawrzyniec Nowak, który w wieku piętnastu lat wyjechał do Niemiec; tam w robotniczych, protestanckich centrach stał się socjalistą; walcząc na froncie I wojny światowej dostał się do niewoli rosyjskiej i mógł na własne oczy zobaczyć rewolucję sowiecką. Następnie pracował na Śląsku i we Francji, gdzie stał się „gniewnym komunistą”. Po powrocie do Polski okazało się, że jego działalność w Luboniu była neutralizowana przez duszpasterstwo ks. Streicha.

Kardynał był pod wrażeniem reakcji wiernych w powierzonych jego trosce archidiecezjach, dla których śmierć kapłana stała się okazją do organizowania wzruszających manifestacji i wyrażania przywiązania do wiary i kleru. „Pamięć o zamordowanym kapłanie jest otoczona nimbem męczeństwa" ${ }^{25}$ - pisał tydzień po zbrodni kard. Hlond. Dzięki temu, zdaniem prymasa, także innym księżom okazywany jest większy szacunek.

Wydaje się, że ostatni akapit listu prymasa do nuncjusza wyrażał coś więcej niż jedynie podsumowanie tragicznych wydarzeń. „Bardzo słusznie zwraca Ekscelencja uwagę na straszną lekcję, jaką to męczeństwo daje społeczeństwu. Próbujemy tu wyciągnąć wszystkie możliwe nauki i konsekwencje" - stwierdzał arcybiskup Poznania. Można w tych słowach usłyszeć echo pytań, które stawiano wówczas w polskim społeczeństwie. Nie bez powodu do akt nuncjatury w Warszawie zawierającej korespondencję w sprawie ks. Streicha dołączono artykuł z „Rycerza Niepokalanej” zatytułowany Czy wstępny

zwycięstwa”, Śp. Ks. Stanisław Streich, „Miesięcznik Kościelny. Organ Archidiecezyj Gnieźnieńskiej i Poznańskiej" 53 (1938) 5, s. 218.

${ }^{23}$ ASV, Arch. Nunz. Varsavia, b. 292, fasc. 1283, 7.3.1938, k. 42: kard. August Hlond do abp. Filippo Cortesiego.

${ }^{24}$ ASV, Arch. Nunz. Varsavia, b. 292, fasc. 1283, 7.3.1938, k. 42: kard. August Hlond do abp. Filippo Cortesiego.

${ }^{25}$ ASV, Arch. Nunz. Varsavia, b. 292, fasc. 1283, 7.3.1938, k. 43: kard. August Hlond do abp. Filippo Cortesiego. 


\section{CZy wStemmy atak Z.S.P.R. men Polske}

Niedawno dokonane morderstwo w Luboniu pod Poznaniem wstrząsnęło do głẹbi spoleczeństwem polskim. Z rąk wywrotowcy, komunisty zginąl gorliwy kapłan katolicki, ks. Stanislaw Streich. Był on powszechnie lubiany i ceniony przez parafian. W przeciagu 3 lat wybudowal nowy kościół i założył wiele stowarzyszeń katolickich. Cieszył siọ

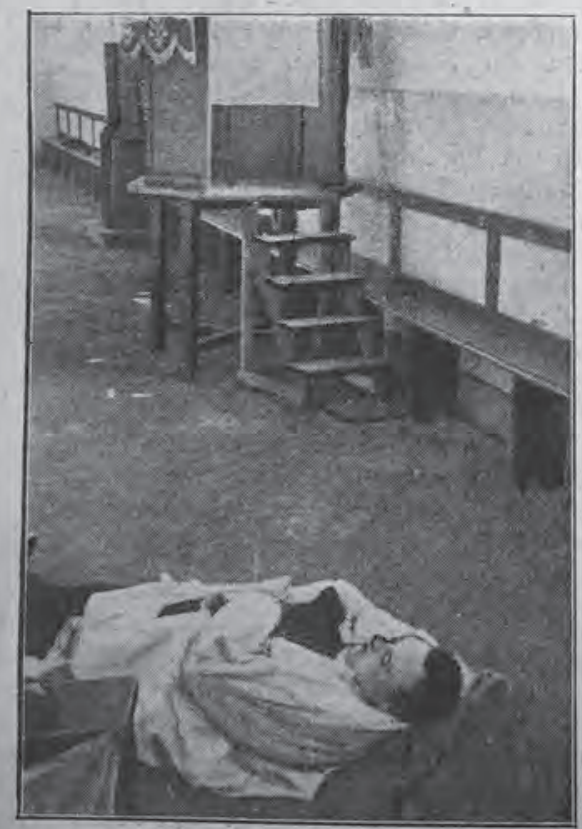

W chwile po zabiciu, ułożono zwloki na posadzce. - W glębi ambona, na ktorej stopniach zostal zabity ks. Streich té̇ zaufaniem u władz dla swej pasterskiej zapobiegliwości. Oddał życie za wiarẹ w kościele, na oczach Eucharystycznego Boga.

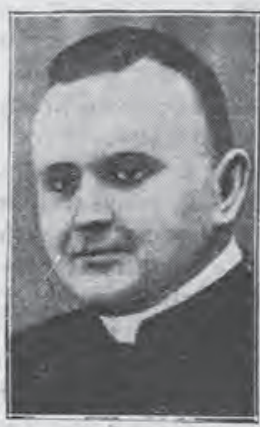
Sp. ks. prob. Streich Ubrany w szaty

liturgiczne, idąc po odprawieniu szkolnej Mszy św. na ambonę, by wygłosić kazanie do dzieci, ugodzony został trzy razy wystrzalem $\mathrm{z}$ rewolweru.

Zabójca ks. Proboszcza, 48-letni Wawrzyn Nowak znany był jako czynny agitator komunistyczny w Wielkopolsce. Powrócił on przed kilkoma laty do Polski z Rosji bolszewickiej, gdzie przedtem przebywal przez 12 lat. Był więc niewątpliwie wychowankiem bezbożniczego komunizmu, który przedtem uśmiercił jego dusze.

Szaleńczy ten czyn nabiera specjalnego znaczenia, tym bardziej, że był on wykonany $z$ rozmysłem. Jest to ostrzegawczy sygnał dla katolików o planowej akcji obozu komunistycznego. To, czego się dżisiaj dopuścil

atak Z. S. R. R. na Polskę $e^{26}$. „Szaleńczy ten czyn nabiera specjalnego znaczenia, tym bardziej że był on wykonany z rozmysłem. Jest to ostrzegawczy sygnał dla katolików o planowej akcji obozu komunistycznego" 27 - pisano w czasopiśmie.

\footnotetext{
${ }^{26}$ Czy wstępny atak Z. S. R. R. na Polskę, „Rycerz Niepokalanej” 4 (1938), s. 111-112.
}

${ }^{27}$ Tamże, s. 111. 
W podobnym tonie redagowano depesze KAP. Katolicka Agencja Prasowa już 2 marca, opisując zdarzenie jako „ohydną świętokradzką zbrodnię”, której motywy nie ulegają wątpliwości - zauważała, że „wywołała ją nienawiść komunistyczna do Kościoła katolickiego i sług Ołtarza”, podkreślała, że wśród komunistów „nienawiść do kapłanów katolickich ma cechy patologiczne"28. „Strzały w kościele w Luboniu to strzały ostrzegawcze. Komintern widocznie pragnie stosować i u nas praktykę wypróbowaną w Hiszpanii. Musi więc napotkać stanowczy opór. Wszyscy zaś winni pamiętać, że lekceważenie niebezpieczeństwa komunistycznego i bezbożniczego jest równoznaczne z tolerowaniem spisku przeciw Polsce"29 - pisano w Biuletynie KAP.

Tydzień po lubońskiej zbrodni mocne przekonanie o realizowanym przez ZSRR ataku na Polskę wyraził na antenie Polskiego Radia abp Józef Teodorowicz. Arcybiskup lwowski obrządku ormiańsko-katolickiego został poproszony o wygłoszenie radiowych kazań pasyjnych, które zostały zarejestrowane, by zachować brzmienie jego głosu dla potomnych ${ }^{30}$. W pierwszym z nich, w długim fragmencie, odniósł się do wydarzeń w Luboniu. Mówił w nim o dopiero co rozpoczętych dziejach nowej Polski w sąsiedztwie „demona Wschodu, który ją nade wszystko wziął za cel swoich pocisków i zamiarów”. „Czyż nas nie ocknie strzał świeżo oddany w kościele w jednej ze wsi poznańskich? Czyż będziemy się dalej czuć bezpieczni, kołysząc się pieśnią fałszywego spokoju?" - pytał abp Teodorowicz. Wyjaśniał przy tym, że strzał godzący we „wzorowego kapłana w chwili spełniania przezeń misji kapłańskiej, jest prawdziwym uderzeniem w wielki dzwon i na ostrzeżenie, że i u nas się pali”.

Takie strzały nie padały dotąd w Polsce, nie padały też w innych kulturalnych państwach, nawet $w$ tych, gdzie prześladują religię. Są one jedynie przeszczepione z wzorów zdjętych z krwawego komunizmu rosyjskiego, są też one czynione i zaprawione jego duchem, są dzieckiem tego ducha. Padły te strzały, godząc śmiertelnie ofiarę, dobijaną jeszcze w kościele nowymi strzałami, pośród okrzy$\mathrm{ku}$ triumfalnego komunisty-zbrodniarza, przemieniającego ambonę Chrystusa w mównicę antychrysta, okrzykiem: „Niech żyje komuna - dla idei to zrobiłem”. Wszystko w tej duszy zbrodniarza odczłowiecza się, wszystko zaprawione jest duchem satanizmu. Sama nawet nienawiść nie ludzka już jest, ale szatańska. Bo człowiek nienawidzi za jakąś krzywdę prawdziwą albo urojoną. A tu wszelki choćby tylko pozór krzywdy nie istnieje. Hasło wniesione na cześć komuny żywcem wyjęte jest z zapasów szatańskich o podbój świata. Strzał nawet sam, chociaż

${ }^{28}$ Zbrodnia w Luboniu, „Biuletyn K. A. P.” nr 50 (2.3.1938).

${ }^{29}$ Tamże.

${ }^{30}$ Por. M. Szczepaniak, Spirala pomówień czy walka o dusze? Wokót polityki na ambonie w kazaniu radiowym abp. Teodorowicza, „Śląskie Studia Historyczno-Teologiczne” 46,1 (2013), s. 129-146. Kazania zostały wydane na płycie CD w 2007 roku przez Fundację Kultury i Dziedzictwa Ormian Polskich. 


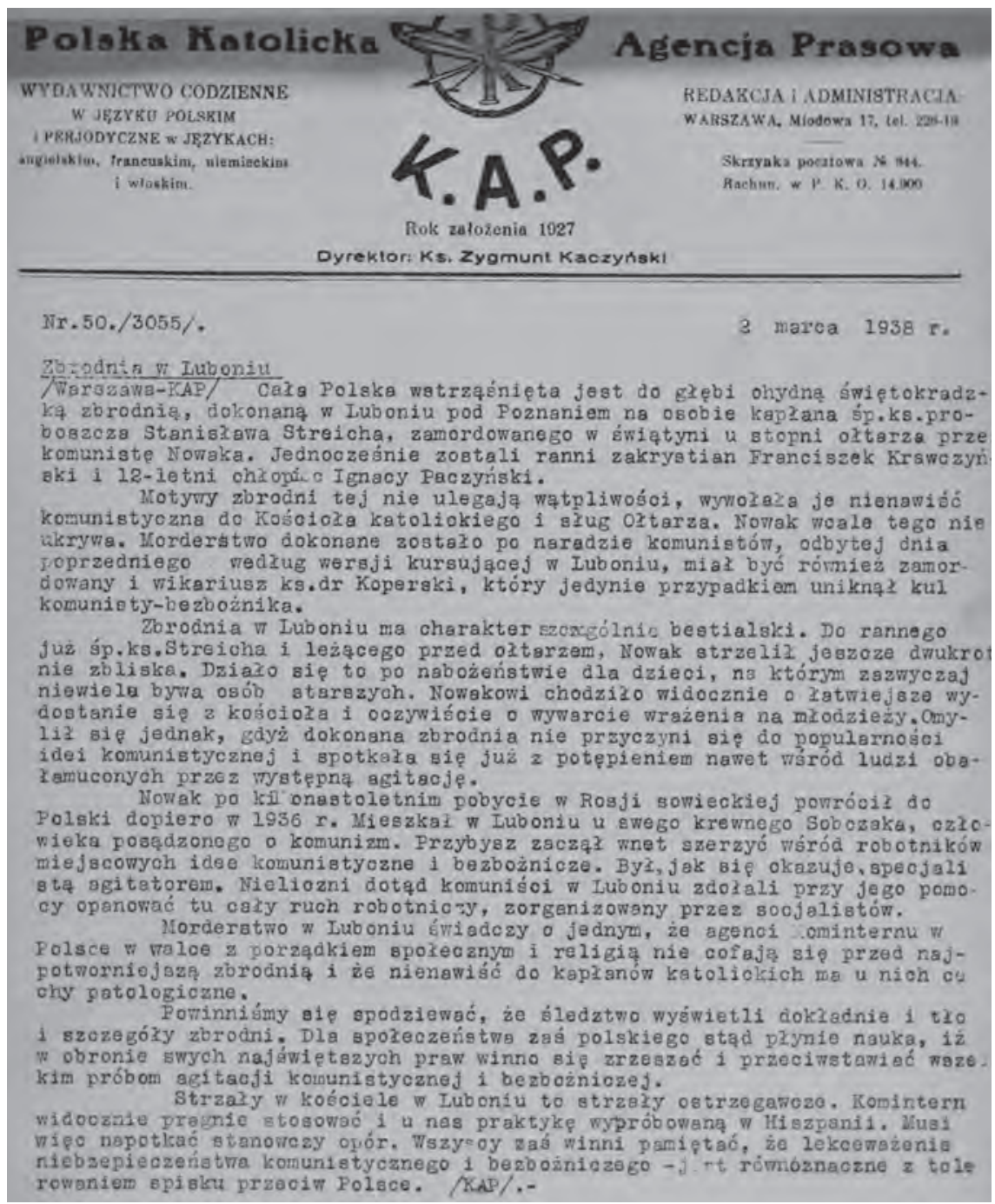

uśmierca kapłana, w istocie jednak godzi w Chrystusa. Tu więc w tym strzale zwarły się ze sobą Królestwo Boże i Królestwo Beliala. Dziś strzał ten ugodził w sługę ołtarza - ale czy nie słyszymy haseł idących z Kremla, głoszonych cynicznie przez urzędowych reprezentantów, iż dążeniem ekspozytur komunizmu jest wszcząć pożar we wszystkich krajach i państwach! Zasięg więc tego strzału dopełniony okrzykiem: „Niech żyje komunizm” - sięga daleko poza ofiarę zbrodni: kapłana i poza Kościół ${ }^{31}$.

31 J. Teodorowicz, Kuszenie Chrystusa. Konferencje wielkopostne wygłoszone w niedziele Wielkiego Postu 1938 roku, Kraków 1938, s. 14-15. 


\section{Dalsze pytania}

Słowa abp. Teodorowicza skupiały jak w soczewce możliwe „nauki i konsekwencje", które - zdaniem opinii publicznej - należało wyciągnąć z morderstwa ks. Streicha. Z prasy wyłaniał się obraz głębokiego poruszenia ${ }^{32}$, ale też wezwanie do solidarności: „Może ta męczeńsko przelana krew śp. ks. Stanisława Streicha, może wizja kapłana zamordowanego u stóp ołtarza, może to wreszcie uświadomi nas, czym jest wywrót i wszystkie jego społeczne i intelektualne przybudówki - może to nas nareszcie skupi wszystkich w solidarne czyny odporu”33 - pisał na łamach „Kuriera Warszawskiego” znany publicysta Adam Grzymała-Siedlecki. Nie dziwi więc fakt, że nuncjusz Cortesi nie omieszkał naświetlić wydarzeń z Lubonia kard. Eugeniowi Pacellemu, sekretarzowi stanu Stolicy Apostolskiej. Zbrodnia została wspomniana jedynie zdawkowo w dzienniku „L'Osservatore Romano” 1 marca wśród „informacji radiowych" ${ }^{34}$. List nuncjusza wysłany do Watykanu był datowany: 9 marca 1938 roku.

„Prasa szeroko opisała świętokradczą zbrodnię, której ofiarą padł niedawno przykładny proboszcz z Lubonia, ks. Streich z archidiecezji poznańskiej, we własnym kościele, podczas spełniania posługi religijnej dla dzieci, na oczach których dokonała się momentalnie krwawa scena" 35 - pisał abp Cortesi. Pismo było bardzo emocjonalne: nuncjusz wspominał rannych - jedenastoletniego chłopca oraz zakrystianina, zaznaczał, że w Poznaniu zapewne nigdy nie przeżywano podobnych wydarzeń i że cała Polska - wznosząc głos sprzeciwu - celebruje uroczyste nabożeństwa żałobne w intencji pobożnego i gorliwego kapłana oddanego klasie robotniczej. „Ten najsmutniejszy fakt, który sam przez się jest symptomem alarmującym i przestrogą dla tych, któ-

${ }^{32}$ Zob. np. artykuły w „Kurierze Warszawskim”, który na pierwszej stronie zamieszczał zdjęcia z pogrzebu (Fragmenty z pogrzebu śp. ks. Streicha [zdjęcia z podpisem], „Kurier Warszawski” nr 62 (4.3.1938), s. 1 [wyd. poranne]) oraz z nabożeństwa ekspiacyjnego w Warszawie („Kurier Warszawski” $\mathrm{nr} 65$ (7.3.1938), s. 1 [wyd. poranne]). Szeroko informowano też o kolejnych wydarzeniach: Manifestacyjny pogrzeb ks. Streicha w Luboniu, „Kurier Warszawski” nr 62 (4.3.1938), s. 6 [wyd. poranne]; Nabożeństwo ekspiacyjne, „Kurier Warszawski” nr 62 (4.3.1938), s. 13 [wyd. wieczorne]; Po pogrzebie śp. ks. Stanisława Streicha, „Kurier Warszawski” nr 63 (5.3.1938), s. 6 [wyd. poranne]; Nabożeństwo ekspiacyjne, „Kurier Warszawski” nr 63 (5.3.1938), s. 12 [wyd. wieczorne]; Nabożeństwo ekspiacyjne, „Kurier Warszawski” nr 64 (6.3.1938), s. 30; Nabożeństwo ekspiacyjne $w$ kościele akademickim, „Kurier Warszawski” nr 65 (7.3.1938), s. 5 [wyd. poranne]; Manifestacja przeciw zbrodni w Luboniu, „Kurier Warszawski” nr 65 (7.3.1938), s. 6 [wyd. poranne].

33 A. Grzymała-Siedlecki, Pod światto. Zbrodnia w Luboniu, „Kurier Warszawski” nr 60 (2.3.1938), s. 3 [wyd. wieczorne].

${ }^{34}$ L'orribile delitto di un comunista polacco, „L'Osservatore Romano” nr 49 (1.3.1938), s. 6.

${ }^{35}$ ASV, Arch. Nunz. Varsavia, b. 292, fasc. 1283, 9.3.1938, k. 44: abp Filippo Cortesi do kard. Eugenio Pacellego. 
rzy wciąż nie widzą coraz większych zagrożeń ateistycznej i komunistycznej propagandy, lub są nieaktywni i prawie obojętni, był w stanie podkreślić tajemną intrygę istniejących organizacji wywrotowych, kierowanych przez znane centra zagraniczne; dlatego też należy się spodziewać, że właściwe organy podejmą środki zaradcze stosowne do zagrożenia, i że wszyscy dobrzy ludzie lepiej odczują obowiązek sprzeciwienia się niszczącemu złu, rozpowszechniając i wprowadzając w życie nauczanie Stolicy Apostolskiej" ${ }^{36}$ - pisał abp Cortesi. Do listu skierowanego do sekretarza stanu nuncjusz załączył wyjaśnienia kard. Hlonda.

\section{$* * *$}

„W Luboniu, wiosce koło Poznania / Tam komunista zastrzelił kapłana / / My starzy i młodzi - módlmy się do Boga / By ofiara zbrodni miała wieczny raj / Niechaj ziemia lekką będzie kapłanowi / Błogosławion będzie ksiądz Stanisław Streich”37 - śpiewano w przedwojennym Luboniu. „Śp. ks. Streicha zabił niejaki Nowak, ale w Nowaku poprzednio zabił już duszę komunizm. I ten sam komunizm zabija wielu takich Nowaków, zabija dorosłych, zabija młodzieńców i sięga po najmłodszych, po tych, którzy jeszcze siedzą na ławie szkolnej”38 - pisano na łamach „Gościa Niedzielnego”, trafnie wskazując na przyczynę zbrodniczego aktu.

Tragiczne zdarzenia w Luboniu odsłoniły z całą mocą niebezpieczeństwa płynące z rozprzestrzeniania się ideologii komunistycznej, na których konsekwencje i nauki przyszło jeszcze Polakom poczekać do trudnych lat powojennych. Ofiara życia kapłana - jak mówił kilkadziesiąt lat później następca kard. Hlonda na stolicy biskupiej w Poznaniu - „stanowiła zapowiedź bliskiej agresji na cywilizację europejską, której dopuściły się wkrótce dwa sprzymierzone totalitaryzmy, narodowy i międzynarodowy socjalizm" ${ }^{39}$. Niepokój nuncjusza apostolskiego w Warszawie i zatroskanie kard. Hlonda stały się ich wyraźną zapowiedzią.

${ }^{36}$ ASV, Arch. Nunz. Varsavia, b. 292, fasc. 1283, 9.3.1938, k. 44r: abp Filippo Cortesi do kard. Eugenio Pacellego.

${ }^{37}$ Por. M. Gryczyński, Ksiądz Stanisław Streich, „Przewodnik Katolicki” nr 45 (2004), s. 24.

${ }^{38}$ Zbrodnia w Luboniu, „Gość Niedzielny” nr 11 (13.3.1938), s. 144.

${ }^{39}$ S. Gądecki, Kandydat na oltarze ks. Stanisław Streich (1902-1938), „Miesięcznik Kościelny Archidiecezji Poznańskiej” 67 (2016) 12, s. 734. 


\section{THE REACTION OF THE NUNCIO IN WARSAW TO THE MURDER OF PRIEST STANISŁAW STREICH}

\section{Summary}

In 1938, a pastor priest of the parish of St. Jan Bosco, Stanisław Streich, was shot in Lubon. The murder was carried out during a service in which about two hundred children participated. The killer communist gave a few shots to the priest, then called from the pulpit: "Long live Communism!". The funeral of the priest became an opportunity for many patriotic manifestations.

The events in Lubon were seen in the perspective of martyrdom, due to the fact that the crime was commited for ideological reasons. They immediately interested the Apostolic Nuncio in Poland, Archbishop Filippo Cortesi, who learned about the details of the murder of the priest from the press. He expressed his regret in writing to Cardinal August Hlond, Primate of Poland and the Ordinary of the priest. The Nuncio also reported the crime to the Secretariat of State of the Holy See. It seems that the letters of the nuncio Cortesi constitute an interesting contribution to the source research concerning the crime in Lubon and Fr. Streich. The author of the article undertakes their analysis based on archival materials collected in Archivio Segreto Vaticano.

Słowa kluczowe: ks. Stanisław Streich, abp Filippo Cortesi, kard. August Hlond, komunizm

Keywors: priest Stanisław Streich, Archbishop Filippo Cortesi, cardinal August Hlond, communism

\section{Bibliografia}

\section{Materiały archiwalne}

Archivio Segreto Vaticano, Arch. Nunz. Varsavia, b. 292, fasc. 1283, 1938.

Archiwum Archidiecezjalne w Poznaniu, Konsystorz i Kuria Arcybiskupia, KA 1107, 1920-1938.

\section{Opracowania}

Gądecki S., Kandydat na oltarze ks. Stanisław Streich (1902-1938), „Miesięcznik Kościelny Archidiecezji Poznańskiej” 67 (2016) 12, s. 731-735.

Gryczyński M., Ksiąz Stanisław Streich, „Przewodnik Katolicki” nr 45 (2004), s. 24.

Mueller W., Błogostawiona krew - męczeństwo Stugi Bożego ks. Stanistawa Streicha, Poznań 2017.

Mueller W., Ksiadz Stanisław Streich, kandydat na ołtarze, „Miesięcznik Kościelny Archidiecezji Poznańskiej” 67 (2016) 7, s. 443-447.

Pryjda M., Sprawa księdza Streicha na łamach prasy, „Rocznik Historyczny Lubonia” 4 (2014), s. 71-132.

Śp. Ks. Stanisław Streich, „Miesięcznik Kościelny. Organ Archidiecezyj Gnieźnieńskiej i Poznańskiej" 53 (1938) 5, s. 218-220. 


\section{Prasa}

Czy wstępny atak Z. S. R. R. na Polske, „Rycerz Niepokalanej” nr 4 (1938), s. 111-112.

Dalsze uchwały w zwiazku ze zbrodnia lubońska, „Kurier Poznański” nr 105 (6.3.1938), s. 12.

Fragmenty z pogrzebu śp. ks. Streicha, „Kurier Warszawski” nr 62 (4.3.1938), s. 1.

Grzymała-Siedlecki A., Pod światło. Zbrodnia w Luboniu, „Kurier Warszawski” nr 60 (2.3.1938), s. 3.

Ks. Kard.-Prymas u trumny, „Kurier Poznański” nr 101 (4.3.1938), s. 5.

Ks. prymasowi w holdzie, „Kurier Warszawski” nr 67 (9.3.1938), s. 5.

L'orribile delitto di un comunista polacco, „L'Osservatore Romano” nr 49 (1.3.1938), s. 6.

Manifestacja przeciw zbrodni w Luboniu, „Kurier Warszawski” nr 65 (7.3.1938), s. 6.

Manifestacyjny pogrzeb ks. Streicha w Luboniu, „Kurier Warszawski” nr 62 (4.3.1938), s. 6.

Nabożeństwo ekspiacyjne, „Kurier Warszawski” nr 62 (4.3.1938), s. 13.

Nabożeństwo ekspiacyjne, „Kurier Warszawski” nr 63 (5.3.1938), s. 12.

Nabożeństwo ekspiacyjne, „Kurier Warszawski” nr 64 (6.3.1938), s. 30.

Po pogrzebie śp. ks. Stanisława Streicha, „Kurier Warszawski” nr 63 (5.3.1938), s. 6.

Rekoncyliacja, „Kurier Warszawski” nr 59 (1.3.1938), s. 14.

Requiem w Poznaniu za spokój duszy śp. ks. Streicha, „Kurier Poznański” nr 105 (6.3.1938), s. 12.

Szczegóły potwornej zbrodni w Luboniu, „Kurier Warszawski” nr 59 (1.3.1938), s. 14.

Zamordowanie ks. St. Streicha w kościele, „Kurier Warszawski” nr 59 (1.3.1938), s. 6.

Zamordowanie proboszcza, „Kurier Warszawski” nr 58 (28.2.1938), s. 5.

Zbrodnia w Luboniu, „Biuletyn K. A. P.” nr 50 (2.3.1938).

Zbrodnia w Luboniu, „Gość Niedzielny” nr 11 (13.3.1938), s. 144. 